\title{
Stone Cairns and Material Culture of the Middle to Late Holocene, LaKe Turkana
}

\author{
David K. Wright, Katherine M. Grillo \& Robert Soper
}

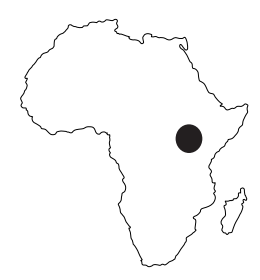

\begin{abstract}
A recent archival research project in the National Museums of Kenya (NMK) identified artifacts and human remains associated with the 1980 excavation of stone cairns and habitation areas on the west side of Lake Turkana. The presence of stone grave cairns across eastern Africa is common, but their cultural origins and construction times are enigmatic. This article presents the results of the archival project and contextualizes both the artifacts found and the unpublished research notes within the framework of evolving settlement patterns in eastern Africa during the middle to late Holocene. Despite the presence of numerous decorative features on ceramics and the recovery of many complete lithic tools, the material culture is generally non-diagnostic within existing typo-technological categories. The research indicates that there was tremendous diversity in the material culture of the Turkana Basin during the late Holocene.
\end{abstract}

\begin{abstract}
Résumé
Un projet de recherche archivistique récemment mené dans les Musées Nationaux du Kenya (NMK) a permis d'identifier des artefacts et des restes humains associés à la fouille datant de 1980 de cairns et de zones d'habitation sur la côte ouest du lac Turkana. La présence de cairns sépulcraux en pierre dans l'Est de l'Afrique est commune, mais leurs origines culturelles et leurs époques de construction restent énigmatiques. Cet article présente les résultats du projet archivistique et replace à la fois les artefacts découverts et les notes de recherche inédites dans le cadre de l'évolution des modes de peuplement en Afrique orientale du milieu à la fin de l'Holocène. Malgré la présence de nombreux éléments décoratifs sur la céramique et la découverte d'abondants outils lithiques complets, la culture matérielle est généralement indifférenciée dans les catégories de typo-technologiques existantes. La recherche indique qu'il y a eu une très grande diversité dans la culture matérielle du bassin du lac Turkana au cours de l'Holocène tardif.
\end{abstract}

Keywords: Pastoral Neolithic, Lake Turkana, Holocene, stone cairns, ceramics, spatial statistics

David K. Wright $\beta$ msafiri@snu.ac.kr

$\triangle$ Department of Archaeology and Art History, Seoul National University, 1, Gwanak-ro, Seoul, 08826, South Korea

and Department of Archaeology, University of York, King's Manor, York, YO1 7EP, U.K.

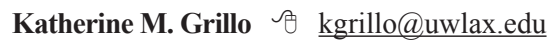

$\bowtie$ Department of Archaeology and Anthropology, University of Wisconsin-La Crosse, La Crosse, WI 54601, U.S.A.

Robert Soper $\beta$ soperrobert72@gmail.com

$\triangle$ Department of History, University of Zimbabwe, Harare, Zimbabwe

DOI 10.3213/2191-5784-10287

(C) The Authors, 2016. Published by Africa Magna Verlag

Received 6 Jul 2015

Revised 26 Feb 2016

Accepted 13 May 2016

Published online 5 Oct 2016

Journal of African Archaeology Vol. 14 (2), 2016, pp. 209-222

This article is available under a Creative Commons Attribution 4.0 International License (CC BY 4.0) Down loaded from Brill.com๑4/26/2023 02:58:08PM 


\section{Introduction}

In December 1980 Robert Soper surveyed part of the western margins of the Lake Turkana strand plain for evidence of early pastoral cultures in the region and recorded 58 archaeological sites in the Standardised African Sites Enumeration System (SASES). Many artifact scatters frequently appeared to be spatially correlated with cairns, which are common grave features found in northern Kenya (see DAVIES 2013 for a general review of cairns in eastern Africa). Commonly thought to date to the late Holocene, these cairns are emblematic of the broader enigmatic state of knowledge concerning archaeological traditions in the areas where they are found. Although there are ware classifications for many ceramic traditions in eastern Africa (WANDIBBA 1980; Collett \& Robertshaw 1983; Soper 1989), conflicting nomenclatures and gaps in classifying the material culture record currently preclude seriation as a useful dating technique. Lithic assemblages in places like the Lake Turkana region are dominated by microlithic scrapers and points, but do not demonstrate patterned diachronic changes until metal became a consistent component of artifact manufacture in recent times.

For this manuscript, field notes have been combed and artifacts reanalyzed in an attempt to contextualize these archaeological data. We compare two archaeological areas with complete survey coverage to examine the spatial distribution of cairn sites. Additionally, two radiocarbon ages were assayed from cultural fill stored at the National Museums of Kenya (NMK). These results demonstrate the apparent heterogeneous distribution of material culture traditions in the Turkana Basin. This article presents the results of the archival project and situates the artifacts and research notes within the framework of evolving environments and human settlement patterns in eastern Africa during the middle to late Holocene.

\section{Physical and social environments of Holocene Lake Turkana}

During the Holocene, Lake Turkana was subject to at least nine $>30 \mathrm{~m}$ magnitude changes in lake level on centennial scales (BLoszies et al. 2015). The final major regression of the lake from $c a 100 \mathrm{~m}$ above the present level to within $10 \mathrm{~m}$ of its current level occurred between 4500 and 4200 years BP (BLoszIEs et al. 2015). The hydrologic history of variable lake levels has created a taphonomic bias against the preservation of archaeological sites below $460 \mathrm{~m}$ a.s.l. (WRIGHT et al. 2015). Additionally, depositional processes that bury archaeological sites are primarily limited to ephemeral streambeds during the late Holocene and there are many deflationary or erosional processes that adversely af- fect sites. This combination of factors means that most archaeological sites from this period typically occur as deflated or lagged surface assemblages.

The taphonomic condition of archaeological sites after 4500 years BP ensures that there is ambiguity associated with the introduction of food production and the settlement dynamics that followed, which post-date the final regression of Lake Turkana (RoBbins 1984; BARTHELME 1985; Wright et al. 2015). After 5500 years BP, it has been argued that new populations of people entered the region, which EHRET (1998: 173) linguistically identifies as "Mbuguan" or Ma'a Southern Cushites, although their association with specific archaeological traditions is highly speculative (ROBERTSHAw 2013). At the same time, it is argued that the indigenous population of the region were Nilo-Saharan speakers who had previously relied on an aquatic-based diet, and incrementally adjusted their subsistence strategies to accommodate the increasingly arid climates they were facing during the middle Holocene (StEWART 1989; EHRET 2013).

The introduction of domesticated animals during the Pastoral Neolithic (PN) correlates to a period of pillar construction (HILDEBRAND \& GRILLO 2012; GRILLO \& HILDEBRAND 2013), but fish and wild fauna remained important elements of subsistence (WRIGHT et al. 2015). Obsidian sourcing of lithics yields results suggesting that boats facilitated contact between different ends of the lake (NDIEMA et al. 2011). Ceramics and mortuary features can provide additional bases for reconstructing the diffusion of cultural traditions. However, descriptive datasets are needed for future construction of typologies, which may, in turn, provide evidence for the presence of biocultural boundaries and/or culture change. Herein, we present data on cairns and surface assemblages of artifacts from Lake Turkana in order to describe and contextualize mosaics of human settlement during the middle to late Holocene.

\section{Research methods}

In December 1980 Robert Soper's recording of archaeological sites on the west side of Lake Turkana was part of the activities of a team from the Institute of African Studies of the University of Nairobi. The other members of the team were collecting material for the Socio-Cultural Profile of Turkana District, mainly concerned with the Turkana people themselves. Archaeological surveys and excavations were undertaken to document the prehistoric demography of the Turkana region. Archaeological sites were recorded in the SASES system and notes and partial surface collections were taken, representing the general attributes of the sites. Archaeological sites were classified on the basis of their primary attributes as either cairns, surface 
artifact scatters, other stone features such as circles of stones, or rockshelters. All archaeological artifacts that were collected were curated in the NMK in Nairobi, which included general descriptions of the artifacts on $4 \times 6$ inch notecards.

In 2012 and 2014, archival research in the NMK was undertaken with a special emphasis on re-cataloguing middle to late Holocene sites across the Turkana region for the purpose of creating a digital database prototype. During the project, thousands of artifacts were repackaged for storage because they were in such a serious state of decay. In total, the project re-catalogued 2192 individual collections, including the addition of high-resolution photography of 602 artifacts and illustrations of 37 artifacts. The catalogue was constructed in Microsoft Access, which will allow for easy export of the data into a permanent museum curatorial software package at a later date.

Due to the extraordinary nature of the assemblage from the aforementioned 1980 Turkana Socio-Cultural Profile research project from western Turkana, special attention was given to documenting the collection. Identifications of ceramic artifacts were reassessed, and a partial re-examination of lithic artifacts focused on photographing tools from the assemblage. One sample of charcoal was submitted to the Seoul National University Accelerator Mass Spectrometer (SNU-AMS) facility and a sample of ostrich eggshell was submitted to the Illinois State Geological Survey (ISGS) for ${ }^{14} \mathrm{C}$ dating. Both samples were taken from excavated subsurface contexts.

The archival research project also included careful examination of original field notes and artifacts curated in association with the Turkana SocioCultural Profile research project. Site locations were plotted in QGIS (www. qgis.org) by converting East Africa Grid coordinates into Universal Transverse Mercator (UTM) coordinates. The present paper also includes survey data collected in 2008 documenting the presence of stone cairns from the Mount Porr region. Methods for the collection of these data are presented in Wright \& FormAN (2011).

Statistical analyses of the distributions of cairn sites from the western

Figure 1. (a) Location of the project area. Red boundary represents the upper elevation of Lake Turkana during the Holocene. (b-c) Numbers correspond to Table 1 (Map key) with bold numbers mentioned in the text or figures.
Turkana and Porr regions were performed as part of the present study. Nearest neighbor (NN) analysis of cairn sites were executed in QGIS 2.12.1. Chi-square tests were executed in software provided by PREACHER (2001). Ripley's K analysis (DIXON 2006) of clustering as a function of distance was performed in ArcGIS 10.2.2, separately on the spatial distribution of cairns recorded from the western Turkana project area (UTM $36 \mathrm{~N}$ ) and the Mount Porr project area (UTM 37N). Ripley's K analysis examines the tendency of features to appear clustered or homogeneously distributed (dispersed) against an expected value that increases linearly as the spatial scale of analysis increases. For the western Turkana project area, a 95\% confidence envelope was determined by 99 Monte Carlo simulations of homogeneity beginning at a scale of $100 \times 100 \mathrm{~m}$ and increasing 100 times at increments of $250 \mathrm{~m}$ for each simulation. Therefore the second simulation tests homogeneity at $350 \times 350 \mathrm{~m}$, the third at $600 \times 600 \mathrm{~m}$, and so on. For the Mount Porr project area, the minimum threshold was set to $10 \times 10 \mathrm{~m}$, increasing 100 times at increments of $10 \mathrm{~m}$.

\section{Research results}

Of the 58 sites recorded during the 1980 survey of western Turkana, 26 were documented as cairn sites and 30 were surface artifact scatters, with seven cairn sites including surface artifact scatters (Fig. 1). Table 1 presents the summary of the sites identified in the 1980 survey and associated cultural materials. The material culture associated with the sites generally included

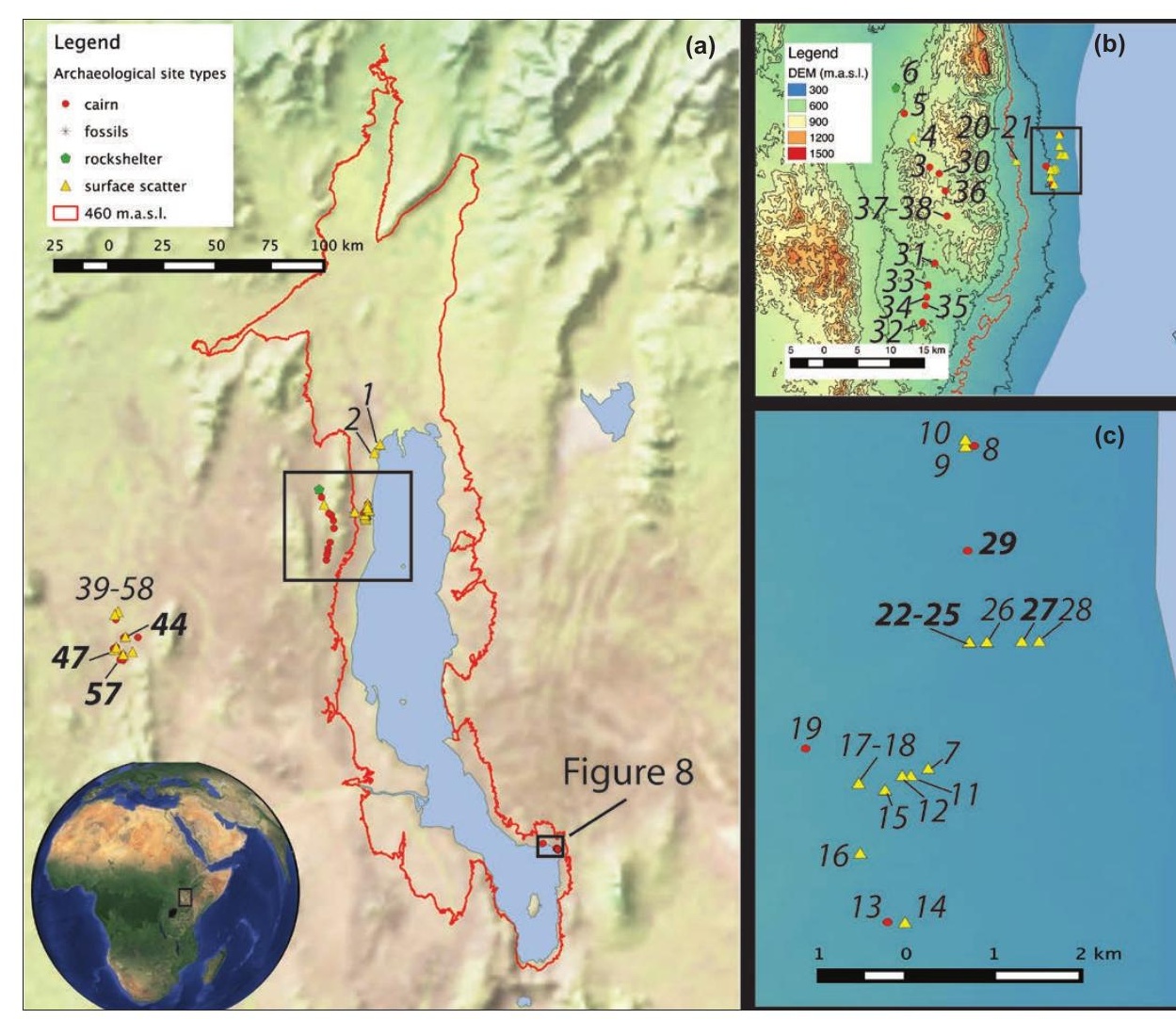




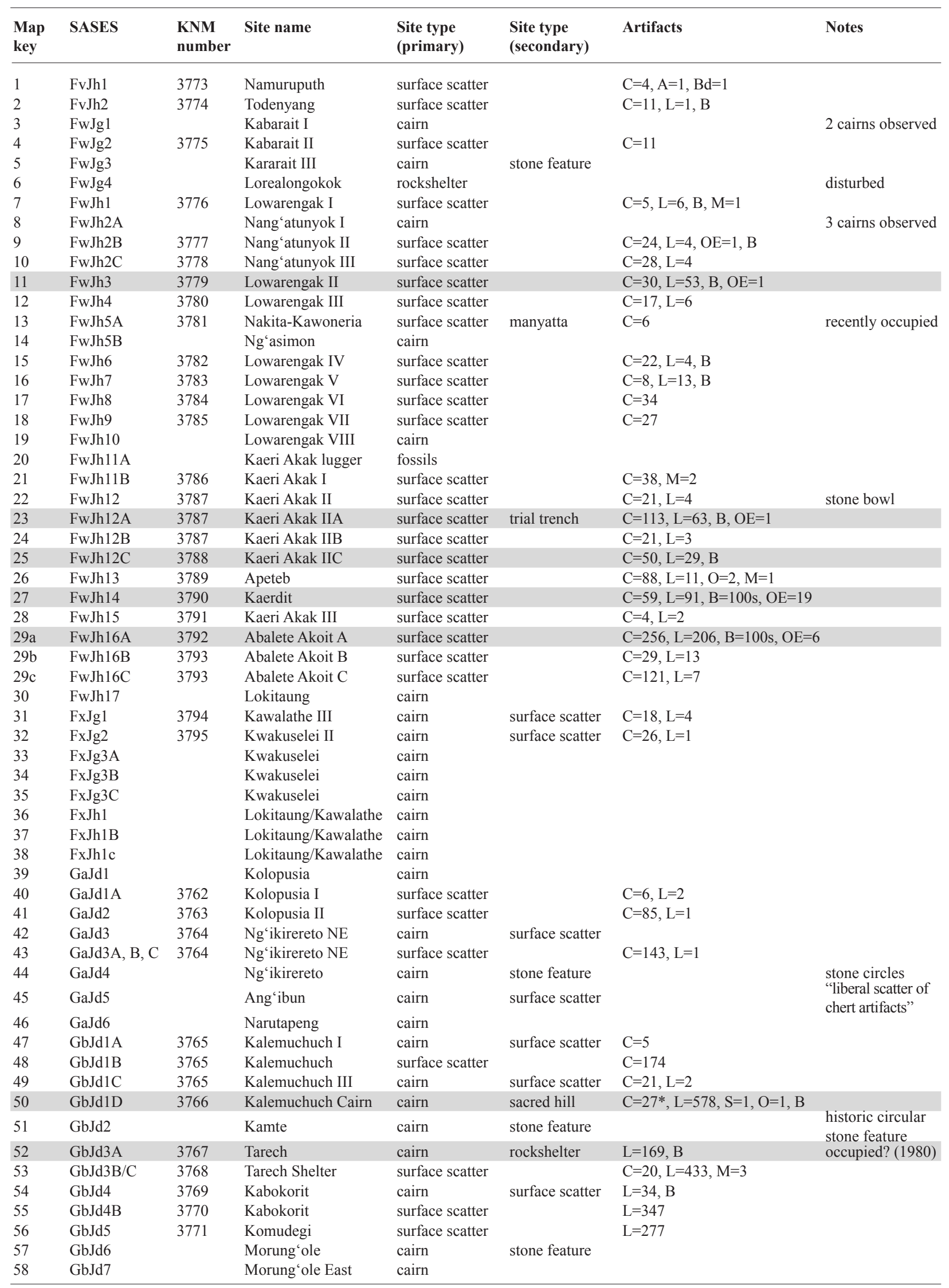

Table 1. Archaeological sites identified during survey and excavated during the 1980 field season. Gray shading indicates that portions of the site were excavated. Sites with a KNM number have associated artifacts curated in the National Museums of Kenya Archaeology Section. Key to artifact categories: $\mathrm{C}=$ ceramics ( $*$ =including complete vessel in Fig. 4), L=lithics, $\mathrm{S}=$ shell, $\mathrm{O}=$ ochre, $\mathrm{B}=$ bone, $\mathrm{M}=$ metal, $\mathrm{A}=$ ammunition casing, $\mathrm{Bd}=$ bead, $\mathrm{OE}=$ ostrich eggshell. Quantities are raw counts of all artifacts. Bone was not generally counted because of the fragmentary nature. "Map key" refers to Fig. 1. 


\begin{tabular}{llllll}
\hline Sample \# & Site & Material & $\boldsymbol{\delta}^{13} \mathbf{C} \% \mathbf{o}$ & ${ }^{14}$ C age BP & cal. age BP \\
\hline GX-8747 & FwJh16A & Charcoal & Unknown & $3370 \pm 190$ & $3160-4150$ \\
SNU13-390 & FwJh16A & Charcoal & -25.32 & $3160 \pm 40$ & $3250-3460$ \\
ISGS-A305 & FwJh14A & Ostrich egg & -5.6 & $1365 \pm 25$ & $1260-1320$ \\
\hline
\end{tabular}

Table 2. Radiocarbon ages generated from archival material analyzed from western Turkana. All ages were calibrated using Version 7.1 of CALIB online software (http://calib.qub.ac.uk/ calib/) sensu REIMER et al. (2013). Calibrated ages are presented at the 2- $\sigma$ confidence interval.

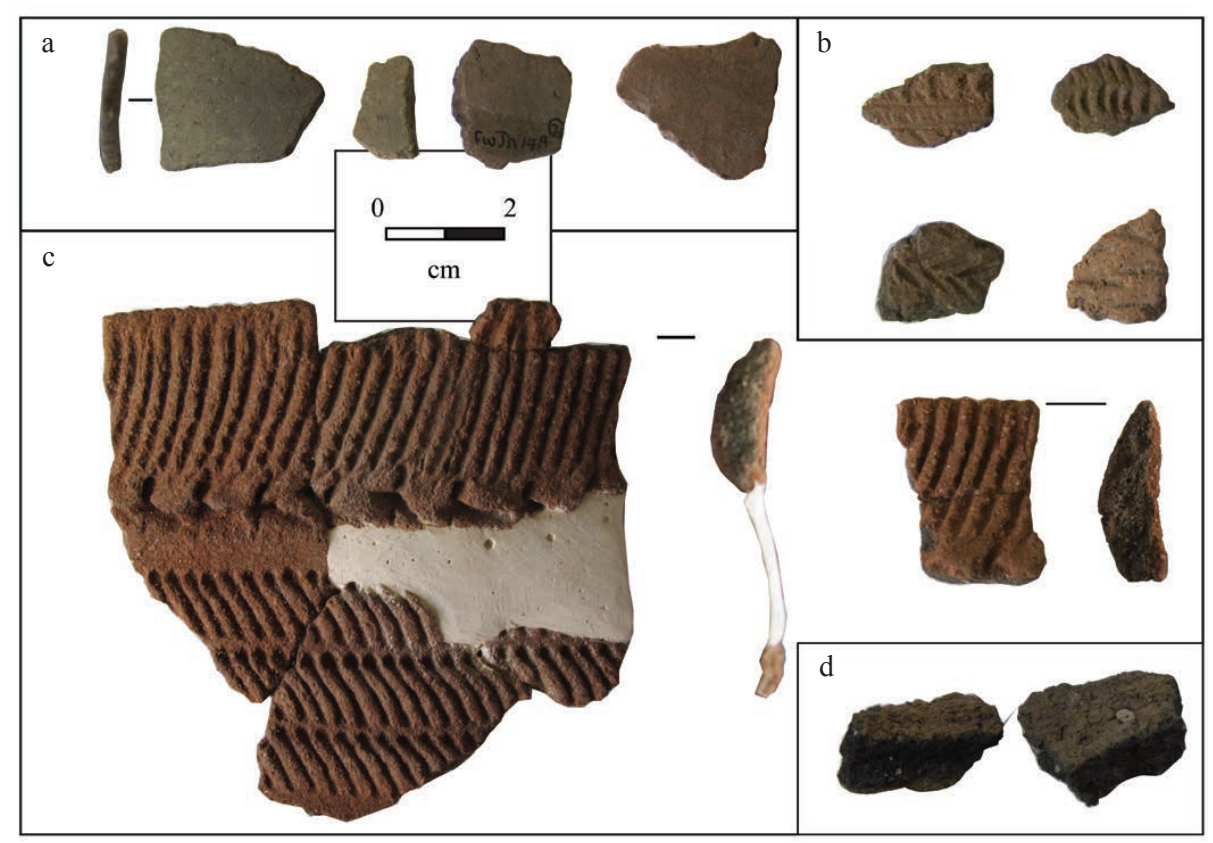

Figure 2. Kaerdit (FwJh14A) 2-12 cm below modern ground surface. (a) Thin walled vessel sherds. (b) Miscellaneous decorated sherds. (c) Comb- or rockerstamped rim sherds. (d) Gritty, vegetal-tempered sherds.

ceramics that did not conform to previously described ceramic typologies for eastern Africa (BOwER et al. 1977; WANDIBBA 1980; SoPER 1989). Similarly, lithics were primarily microlithic flakes and tools such as scrapers made on locally available chert and obsidian, which are common in the toolkits of Later Stone Age (LSA) sites from across the Rift Valley (Bower et al. 1977; Bower 1991; Ambrose 1998; BARUt-Kusimba 1999).

Test pits were dug on seven sites identified during the 1980 field season. The site of Kaerdit (FwJh14A) was excavated in two levels $(2-3 \mathrm{~cm}, 2-12 \mathrm{~cm})$ following a total surface collection. Artifact collections include microliths, ceramics and fauna remains. A sample of unmodified ostrich eggshell from Level 2 (2-12 cm below the ground surface) analyzed in 2014 yielded an age of $1365 \pm 25{ }^{14} \mathrm{C}$ yr BP (1260-1320 cal yr BP; Table 2).

Ceramics recovered from the surface at Kaerdit (Fig. 2) and other sites in western Turkana exhibit a variety of paste types, forms and decorative styles. The majority of the sherds are from undecorated, thickwalled utilitarian vessels. These sherds exhibit evidence for what appears to have been a vegetal temper such as grass or dung. Several non-diagnostic, undecorated sherds are much thinner, one of which has unidentified white mineral inclusions. Other sherds exhibit a variety of decorative motifs, including one with an incised herringbone pattern. One heavily weathered rim with a reddish sandy paste appears to be from an open-mouthed jar and has a comb- or rocker-stamped decorative motif. Two stone bowl fragments and grooved sherds (Fig. 3) were also recovered at the nearby site of Kaeri Akak IIA (FwJh12A). Kalemuchuch Cairn (GbJd1D) included thin-bodied ceramic vessels similar to what was recovered from Kaerdit (Fig. 3). Thin-bodied sherds were also found in the fill at the Kalokol Pillar Site (HILDEBRAND et al. 2011), but the assemblages from Kalemuchuch Cairn and Kaerdit are too small and fragmented to draw additional conclusions. Kalemuchuch Cairn was excavated and included in situ human remains interred with a large jar decorated with coils applied to the exterior surface of the vessel (Fig. 4). This vessel type was also reported from the Mount Porr region on the southeast side of Lake Turkana (WRIGHT \& FORMAN 2011), although originally described as "corrugated." 


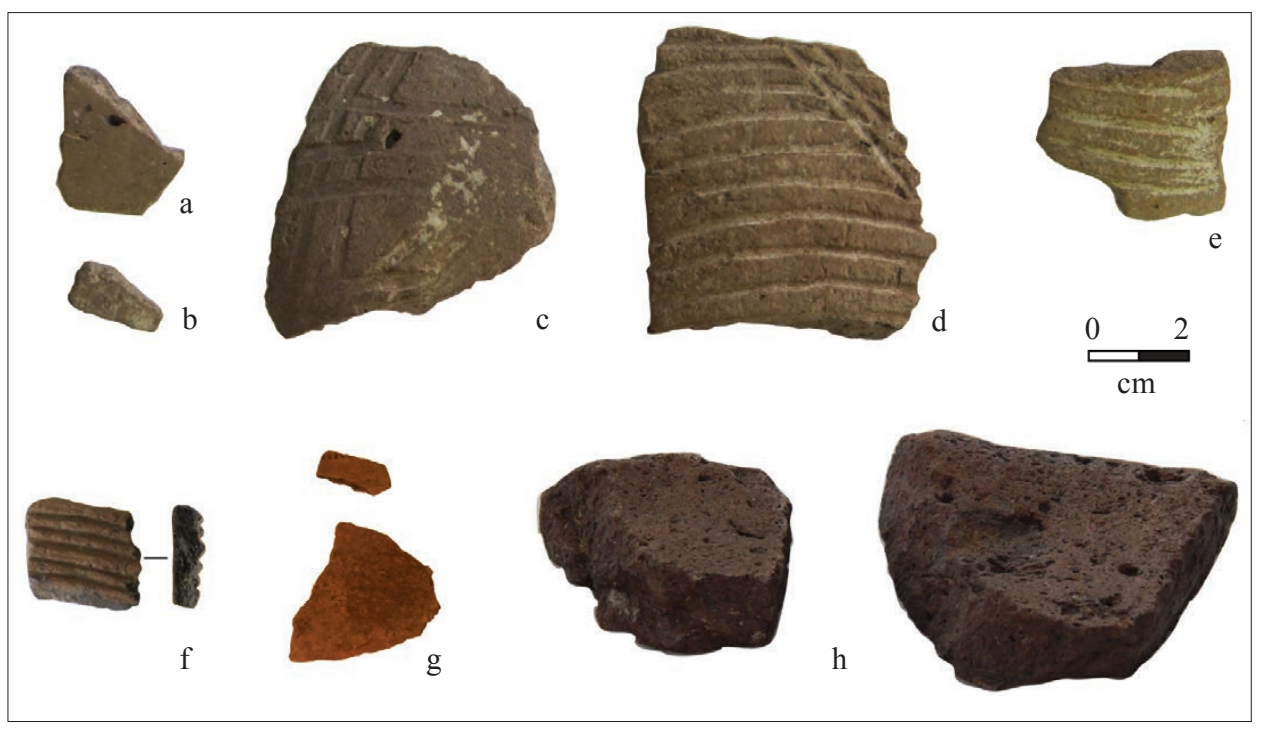

Figure 3. $(\mathrm{a}-\mathrm{e})$ Kaeri Akak IIA (FwJh12A) incised sherds from $12-22 \mathrm{~cm}$ below modern ground surface. (f) Kaeri Akak IIB (FwJh12B) grooved sherds from ground surface. (g) Kalemuchuch Cairn (GbJd1) ground surface. (h) Kaeri Akak IIA (FwJh12A) stone bowl fragments from ground surface.

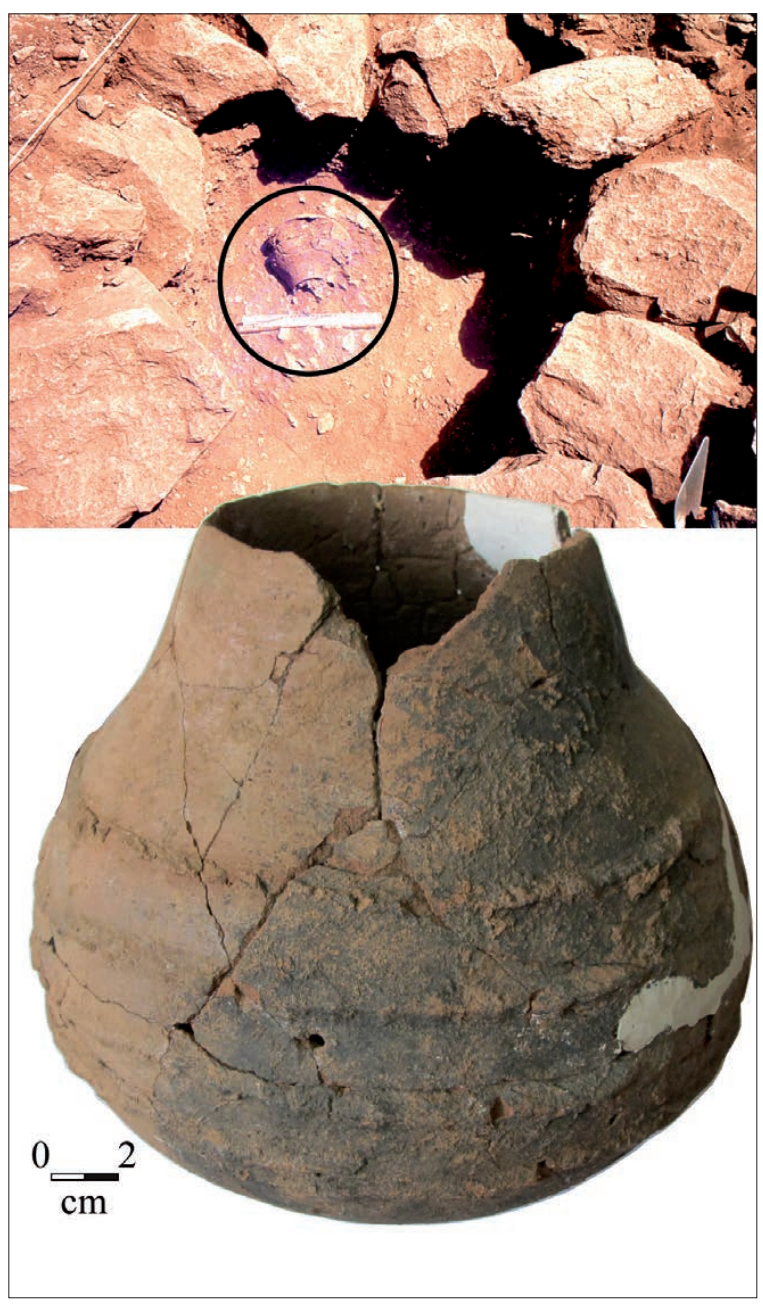

Figure 4. Jar with coils applied to the vessel exterior from Kalemuchuch Cairn (GbJd1) in situ (circled) and reconstructed in the National Museums of Kenya.
Cairns from western Turkana bear resemblance with three of the types documented in DAVIES (2013). Kalemuchuch cairn structure resembles the "kerbed" type (Fig. 5a) in which larger supporting stones are placed in a ring to support smaller stones that are placed on top (DAVIES 2013). Simple cairns (Fig. 5b) and one ringed cairn (Fig. 5c) are also documented. However, discrimination between simple and kerbed cairn structures often requires excavation, so it is impossible to completely account for the cairn types in the survey region until further excavation work is undertaken.

An open-air site, Abalete Akoit (FwJh16A), was excavated in three levels and included dense cultural remains of $>1 \mathrm{~kg}$ charcoal, grooved/incised and other decorated pottery (Fig. 6), lithics, animal remains (three ostrich eggshell fragments, one fish spine and one tooth fragment of a medium-sized bovid) and unburned human remains. A notecard in the collection indicates that a radiocarbon age of $3370 \pm 190{ }^{14} \mathrm{C}$ yr BP (3160-4150 cal yr BP; Table 2) was generated from a charcoal sample taken from the middle fill of the cairn (see also Robertshaw 1984). A sample of charcoal from the fill was submitted to Seoul National University AMS lab for radiocarbon analysis and provided an age of $3160 \pm 40{ }^{14} \mathrm{C}$ yr BP (3250-3460 cal yr BP; Table 2).

Several ceramic sherds from Abalete Akoit have decorative patterns covering their entire exterior surfaces (Fig. $6 \boldsymbol{a}-\boldsymbol{g})$. These sherds do not resemble any previously documented early to middle Holocene ceramic types. It appears that vessels were very lightly grooved in one direction, and then deep perpendicular lines were grooved over the initial step. Sherds are light brown in color, and have a relatively coarse and somewhat sandy 

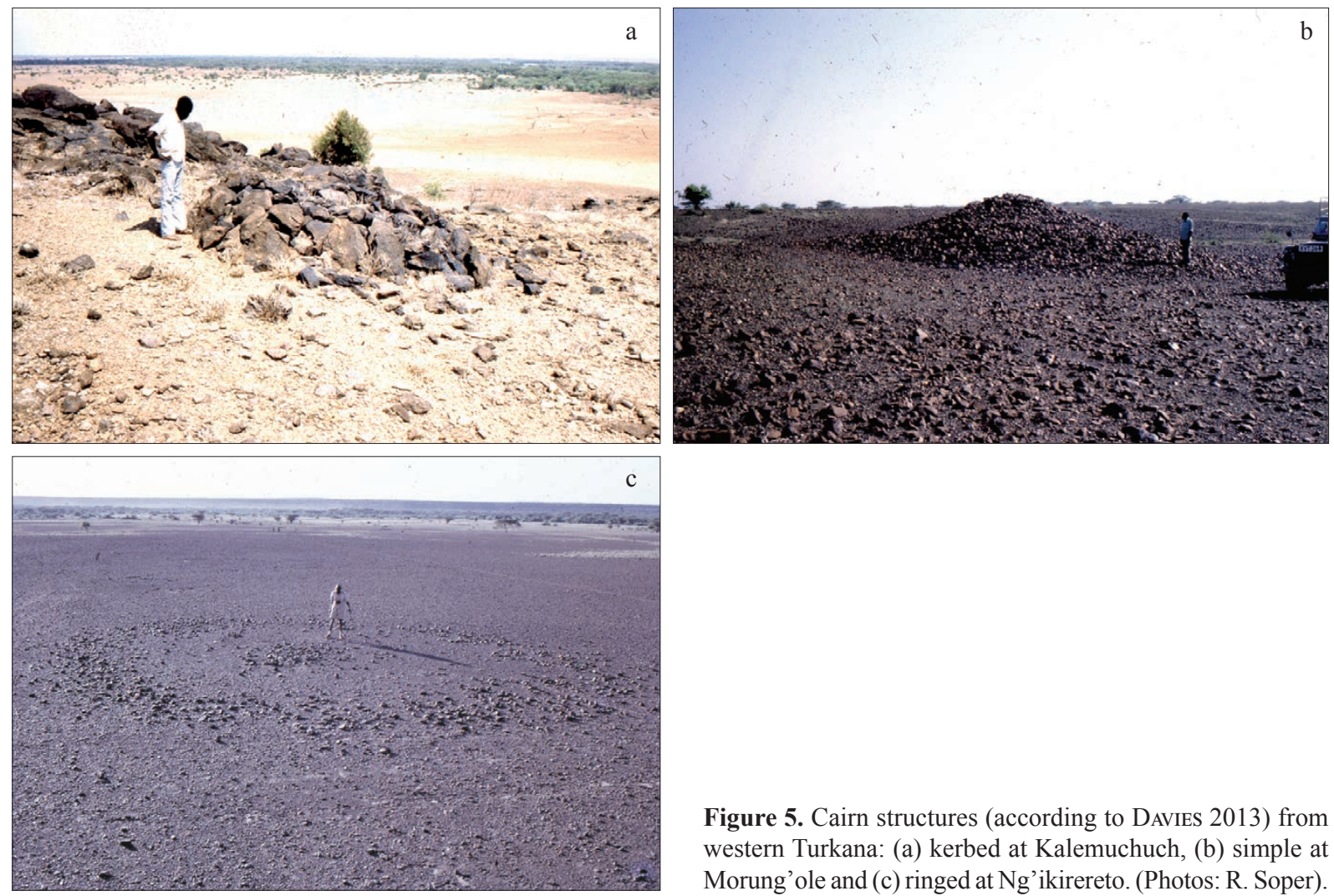

Figure 5. Cairn structures (according to DAVIES 2013) from western Turkana: (a) kerbed at Kalemuchuch, (b) simple at Morung'ole and (c) ringed at Ng' ikirereto. (Photos: R. Soper).

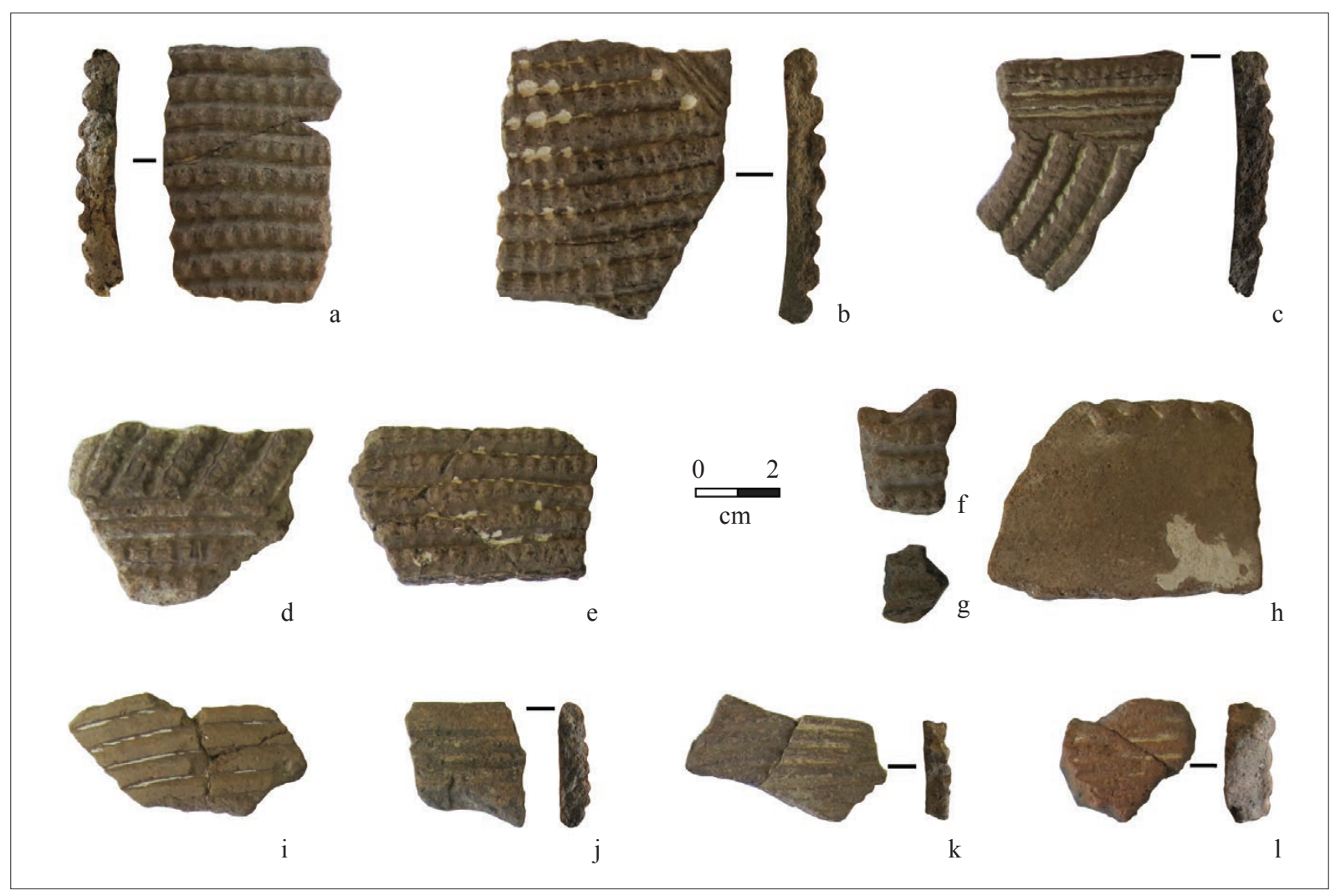

Figure 6. Abalete Akoit (FwJh16A) (a-b) Decorated sherds from the ground surface. (c-g) Decorated sherds from Unit A, $0-10 \mathrm{~cm}$ below ground surface. (h) Unit A, $0-10 \mathrm{~cm}$ below ground surface, rim with pinched design on top edge. (i-1) Grooved/incised sherds from the ground surface. 
fabric. They are not as dense or as finely made as Nderit tradition ceramics. Interior surfaces appear to be very distinctly burnished. Rims are undecorated.

Grooved sherds from Kaeri Akak and Abalete Akoit resemble "Turkwel" ceramic traditions ( $\mathrm{LYNCH}$ \& RobBins 1979; RobBins 1984), but variability in manufacturing techniques associated with grooved sherds observed in the present assemblage was too great to assign them to a coherent "tradition". Undecorated, thin-walled sherds were also recovered in abundance from surface contexts and Kalemuchuch Cairn and Kaerdit. In general, the ceramics are all interpreted as "post-Nderit" assemblages on the basis of radiocarbon ages obtained and their position as surface scatters on the post-4500 year BP strand plain, which occurs below $460 \mathrm{~m}$ a.s.1. (Fig. 1). No similarities in either manufacturing technique or decorative motifs were documented between the western Turkana assemblages and Nderit traditions. Lithic tools were primarily scrapers/processing tools (Fig. 7) commonly found in PN assemblages from elsewhere in the Turkana Basin (e.g., RobBins \& LYNCH 1978; RobBINs 1980; BARTHELME 1985), but the lack of temporally- diagnostic, typo-technological categories of lithics for the region precludes making further interpretations about the significance of these finds.

Cairns associated with LSA sites have been reported from the Mount Porr region (Wright \& FoRMAN 2011), but details of the sites were not provided in the original publication. In total, 40 cairns were recorded including one rather significant cluster of 38 cairns designated GeJk29 (Fig. 8). None of these cairns were $>2 \mathrm{~m}$ in diameter and all were $<1 \mathrm{~m}$ high. Several of the cairns were encircled by a ring of larger stones and then centered with smaller stones (e.g., Fig. 9a, 9b), which DAvies (2013) describes as "kerbed cairns." However, the more common type of cairn was the "simple cairn" (DAVIES 2013), although because none of the cairns were excavated, it is impossible to confirm that kerbs were not located deeper in the substructure of the features. One non-decorated pottery sherd and two lithic tools were recovered from the ground surface of GeJk29.

Since excavations of cairns were not made during the 2008 fieldwork - only site locations were

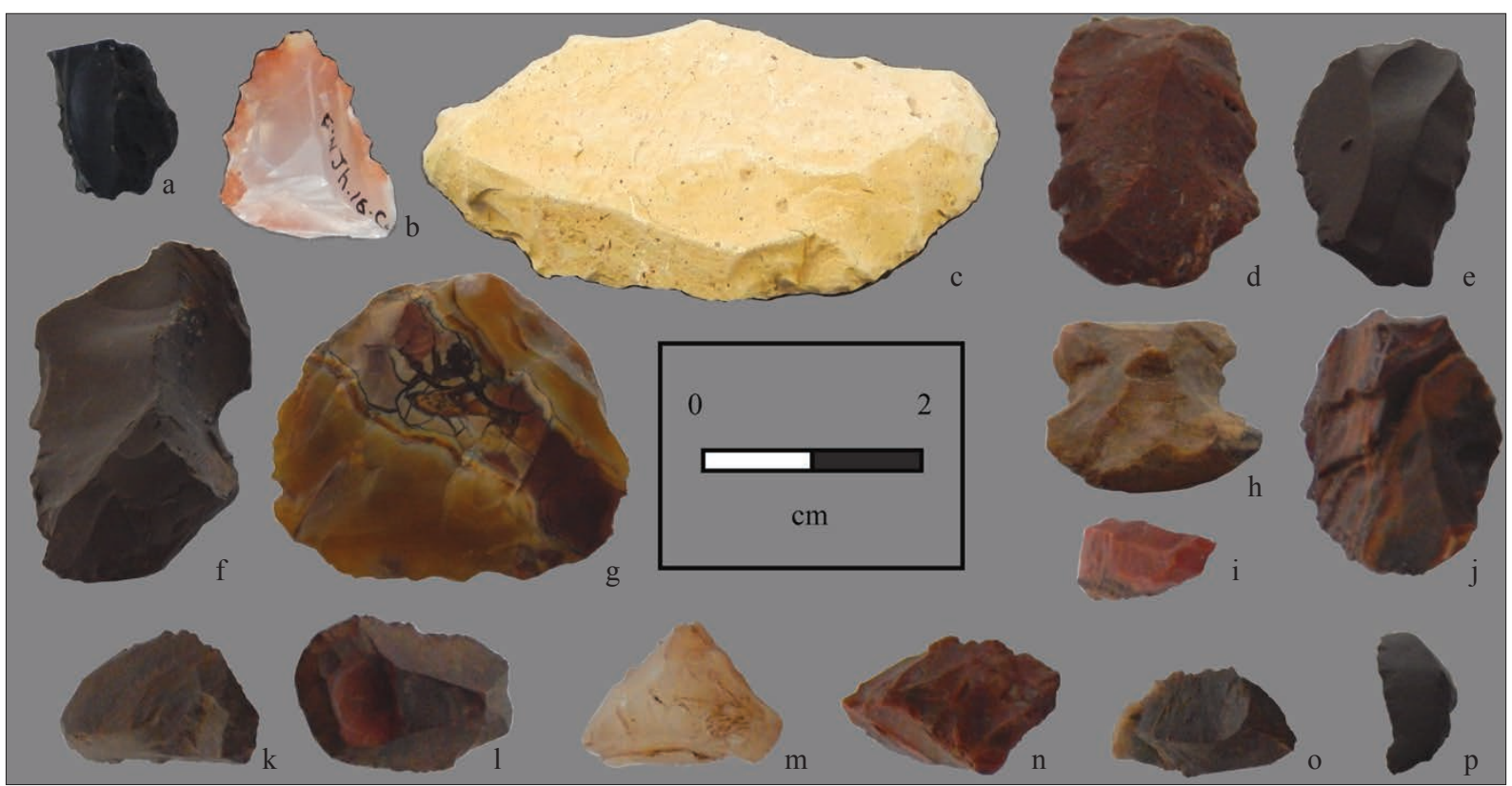

Figure 7. Lithic scrapers and crescents from western Lake Turkana. All artifacts are general surface finds unless otherwise noted. (a) Black chert scraper from Abalete Akoit (FwJh16A). (b) Chalcedony steep backed scraper from Abalete Akoit (FwJh16B), Area C. (c) Sandstone side scraper from Kawalathe III (FxJg1). (d) Jasper scraper from Lowarengak IV (FwJh6). (e) Chert scraper from $\mathrm{Ng}^{\prime}$ ikirereto NE Cairn (GaJd3). (f) Chert nose scraper from Kalemuchuch Cairn (GbJd1A), Area C. (g) Chalcedony scraper from Kalemuchuch Cairn, Area C. (h) Chert scraper with side notches for hafting from Kalemuchuch Cairn, Area C, 0-5 cm below surface (b.s.). (i) Chert side scraper or crescent from Kalemuchuch Cairn, Area C, 5-10 cm. (j) Banded chert nose scraper from Kalemuchuch Cairn, Area C, 0-5 cm b.s. (k) Chert scraper or crescent from Kalemuchuch Cairn, Area C, 5-10 cm b.s. (1) Chert scraper from Kalemuchuch Cairn, Area C, 5-10 cm b.s. (m) Quartz backed scraper from Kalemuchuch Cairn, Area C, 5-10 cm b.s. (n) Jasper backed scraper from Kalemuchuch Cairn, Area C, 5-10 cm b.s. (o) Crescent from Kalemuchuch Cairn, Area C, 5-10 cm b.s. (p) Black chert scraper or crescent from Tarech Cairn $(\mathrm{GbJd} 3 \mathrm{~B} / \mathrm{C})$. 


\begin{tabular}{lcccccc}
\hline Locale & $\begin{array}{c}\text { Observed mean } \\
\text { distance }(\mathbf{m})\end{array}$ & $\begin{array}{c}\text { Expected mean } \\
\text { distance }(\mathbf{m})\end{array}$ & Area $\left.\mathbf{( k m}^{\mathbf{2}}\right)$ & $\mathbf{N}$ & NN index & Z-score \\
\hline W. Turkana & 1597.09 & 8617.35 & 3125.5 & 30 & 0.185 & -8.54 \\
(east) & 1599.62 & 3067.68 & 464.3 & 17 & 0.528 & -3.72 \\
(west) & 1593.78 & 2151.43 & 236.6 & 13 & 0.741 & -1.79 \\
\hline Porr & 42.09 & 60.92 & 0.2 & 38 & 0.691 & -3.65 \\
\hline
\end{tabular}

Table 3. Nearest neighbor (NN) analysis of the western Turkana and Mount Porr regions generated in QGIS. NN indexes for cairn distributions from the eastern (Fig. 1: 1-38) and western (Fig. 1: 39-58) portions of the project areas were generated separately in gray highlighting.
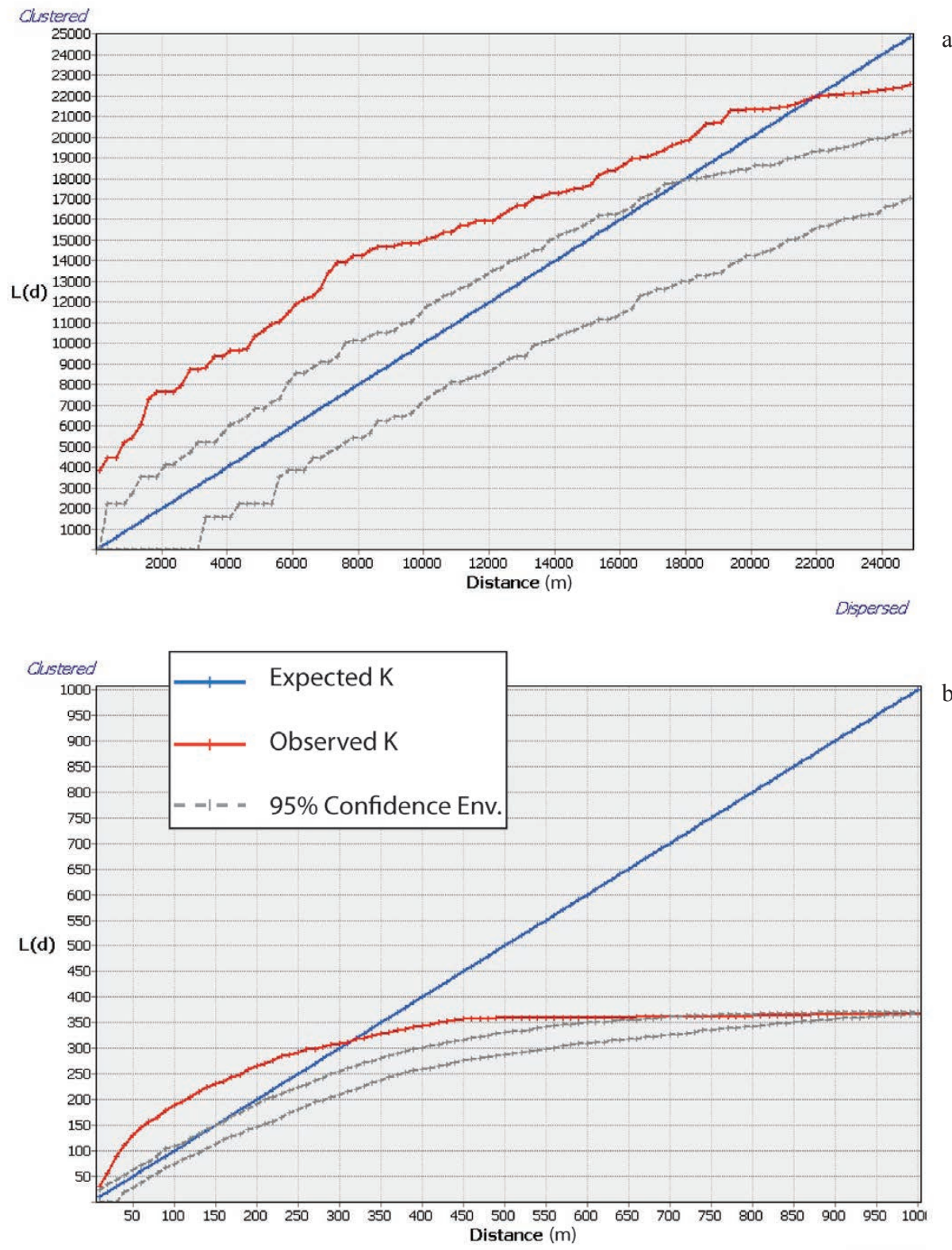

Dispersed

Figure 10. Results of the Ripley's K function analysis. (a) Western Turkana project area; (b) Mount Porr project area. 


\section{Discussion}

Spatial distributions of archaeological sites in the Turkana Basin relative to the position of the modern-day lake are critical data for understanding late Holocene settlement dynamics. The location of Abalete Akoit is significant as it is located approximately $19 \mathrm{~m}$ above the modern lake level and the time of occupation of this site dates to ca 3350 years BP (Table 2). The archaeological evidence agrees with recent lake level reconstructions arguing that regression of Lake Turkana had been completed by 4500 years BP and marked the transition to more permanently arid conditions (GARCIN et al. 2012; FormAN et al. 2014; MORRISSEY \& SCHOLZ 2014; Bloszies et al. 2015; Wright et al. 2015).

Based on archaeological survey data from Mount Porr and western Turkana, the distribution of cairns in the Turkana region appears to be preferentially located on the shoulders of upland ridges (Fig. 1), although four cairns in the western Turkana region and two in the Mount Porr region are located on the strand plain. In the Mount Porr region on the east side of the lake, cairns are clustered with an average ( $\mathrm{NN}$-generated) spatial mean of $42 \mathrm{~m}$ between each documented feature. There are very few associated artifacts with these cairns. Heavy rains falling in the upland locations and wave action on lowland areas may have eroded whatever artifacts were present in the past. However, GeJk29 is not interpreted as having been a habitation area because cairns occupy virtually every low-slope space on its landform.

This stands in contrast to the site pattern observed on the western side of Lake Turkana in which cairns tend to be relatively isolated (mean distance of $1597 \mathrm{~m}$ between each cairn), and seven cairn sites are associated with material culture such as ceramics and lithics. For 24 out of 31 cairn sites Soper documented in western Turkana there are no or very few artifacts associated with the sites. However, given the deep time history that the landscape has been inhabited and slow rate of sediment accumulation in this area, the correlation between cairns and artifact scatters is not necessarily temporally synchronous. Cairns are found in association with several pillar sites that contain rich artifact assemblages across the Turkana Basin (SOPER \& LYNCH 1977; Nelson 1993; Hildebrand \& GRILlo 2012; Grillo \& HildeBrAND 2013), although these cairns are not yet well-dated and their relationships to the main phases of pillar site construction are poorly understood.

Stylistic overlap between artifacts recovered across the Turkana Basin attests to the wide distribution of certain forms of material culture. Coils applied to the exterior of ceramics have been recovered from both the Mount Porr (Wright \& Forman 2011) and Kalemuchuch cairn areas. Grooved pottery has been recovered from surface assemblages across the western side of Lake Turkana (LyNCH \& RoBBINs 1979; RobBins 1984). The use of "stone bowls" is now documented from both east (BARTHELME 1985) and west (Kaeri Akak II) sides of the basin. These data agree with obsidian sourcing that indicates wide zones of material culture exchange post-dating the final regression of the lake (NDIEMA et al. 2010; NASH et al. 2011; NDIEMA 2011), which likely also included exchanges of information and intangible cultural expressions that have not survived in the archaeological record.

Population geneticists use the term "population diffusion" or "demic diffusion" to describe the movement of people from one homeland to another area that they did not previously inhabit, which may (or may not) result in the displacement, intermixing or replacement the indigenous people in the new area (CAVALLI-SFORZA 2000). Linguistic anthropologists have argued that population diffusions of Nilo-Saharan speakers (EHRET 1998, 2013), southern Cushites (LYNCH \& RoBbins 1978, 1979; EHrET 2002, 2011: 212) and eastern Cushites (SCHLEE 1989: 153) into the Turkana Basin could have introduced new mortuary and tool manufacturing traditions with each successive wave of immigrants. However, the heterogeneous nature of the archaeological assemblages from the Turkana region - even within dated, excavated contexts - does not provide explicit, diachronic evidence for sequential culture change. Neither do the data refute the possibility that the demic diffusion of people or cultural transmission of technologies impacted the archaeological record. Cairn construction techniques themselves from the study areas of Porr and western Turkana are either simple or kerbed with a few ringed cairns documented, which is consistent with documented occurrences elsewhere in eastern Africa (DAVIES 2013). Although the wide spatial and apparent temporal distribution of specific cairn construction techniques (such as kerbing or ringing) throughout eastern Africa demonstrates regional exchange of ideas, the degree to which linguistic or genetic diffusion affected how people constructed specific cultural features remains ambiguous.

Certainly, the lack of temporally and spatially recognizable diagnostic attributes in artifacts or feature construction is partially due to the lack of well-dated archaeological assemblages from the region. Future research in this region should concentrate on recovering and dating in situ archaeological remains in order to provide diachronic attribute data that would assist in understanding diffusion of technologies and/or culture change in the face of environmental changes related to fluctuating lake levels. Additionally, better survey data are needed to identify the locations and construction techniques of cairns. Locations of cairns that were part of the present study identified a significant tendency to 
cluster, but more total coverage surveys of the region will demonstrate whether these are anomalous findings or part of a broader spatial pattern across the Turkana Basin.

\section{Conclusion}

A collection of artifacts recovered in 1980 and presently housed in the NMK provides new spatial and chronological data for late Holocene material culture and mortuary traditions in the Turkana Basin. Stone cairns spatially distinct from pillar sites were constructed for mortuary purposes and are associated with technologies that are not diagnostic to existing archaeological typologies within the PN. However, the association of the cairns with PN technologies constrains their likely construction to within the last 5000 years. NN indexes for the cairns were $<0.8$, indicating significant spatial clustering of cairns, but Ripley's K function analysis demonstrates closer spatial clustering in Porr compared to the western Turkana portion of the study region.

Available radiometric dates, location of some sites on the final regressional strand plain and the association with PN artifacts indicate that construction of these cairns occurs after the final major regression of Lake Turkana after 4500 years BP (see also DAviEs 2013), which resulted in a drastic shift in the ecology of the basin toward arid conditions (Forman et al. 2014; BloszIES et al. 2015). At present, there is not enough archaeological data to infer a definitive beginning or end of these mortuary practices, but many of the features post-date the inferred end of construction at the pillar sites since their locations would have been under water prior to 4500 years BP. The persistent use of burial cairns by the Rendille inhabitants of the region (as well as Somalis and other eastern Cushitic speaking populations according to SCHLEE 1989: 153) attests to the utility and presumed cultural importance of this form of internment.

Presently, there is a paucity of archaeological data from the late Holocene of the Turkana Basin, which can only be resolved by further investigations of archaeological assemblages from the post- 4500 years BP regressive strand plain. Archival research, in particular, is direly needed because many collections hosted in the NMK contain rich bodies of evidence from this period, but have yet to be studied or published. In particular, developing a chronometric framework for the evolution of material culture traditions would help resolve relationships between mortuary features and settlement dynamics. The majority of the cairn sites identified in the 1980 field season have yet to be excavated and dated (as well as known cairns from elsewhere across Africa that have received virtually no documentation as cited in DAVIES 2013). The current confusion stemming from the lack of a useful later Holocene ceramic typology for the Turkana Basin could be improved with a concerted effort to directly date organics in sherds using the AMS ${ }^{14} \mathrm{C}$ method. This is particularly the case for those sherds that would perhaps otherwise be lumped as miscellaneous "Iron Age" because they do not seem to conform to existing typologies. The study of aDNA from bioarchaeological remains would also illuminate relationships between past and modern people. Unlocking the secrets of the rich archaeological traditions of this region would serve to shed more light onto migration corridors, economic strategies and technological changes that proved crucial in the development of subSaharan African societies in the late Holocene.

\section{Acknowledgements}

This work was supported by 'Overseas Training Expenses for Humanities' through the College of Humanities, Seoul National University (SNU) in 2014. The BIEA and University of Nairobi African Studies Institute sponsored the original research in 1980 that brought RS to western Turkana and was helpful in assisting DKW in the archival pursuit of field notes and materials. Archival research was conducted with permission from the Office of the President of the Republic of Kenya (permit MOHEST $13 / 001 / 30$ C 220) and in collaboration with the National Museums of Kenya Department of Earth Sciences. Primary research that led to the discovery of GeJk29 was supported by the National Geographic Society Committee for Research and Exploration grants \#8142-06 and 8456-08. The National Research Foundation of South Korea (Grant \#2013S1A5A8021512) and the Research Settlement Fund for new faculty of Seoul National University funded archival research and radiocarbon dating of the western Turkana sites. The Department of Archaeology at the University of York generously hosted DKW and provided access to GIS facilities while he was on sabbatical preparing this manuscript. John Munyiri of the National Museums of Kenya took several photographs of the lithics and ceramics included in this manuscript. We would like to thank two anonymous reviewers and editors for their helpful suggestions that greatly improved the quality of this manuscript.

\section{References}

Ambrose, S.H. 1998. Chronology of the Later Stone Age and food production in East Africa. Journal of Archaeological Science 25 (4), 377-392. http://dx.doi.org/10.1006/jasc.1997.0277

Barthelme, J.W. 1985. Fisher-Hunters and Neolithic Pastoralists in East Turkana, Kenya. BAR International Series 254, Oxford.

Barut-Kusimba, S. 1999. Hunter-gatherer land use patterns in later Stone Age East Africa. Journal of Anthropological Archaeology 18 (2), 165-200. http://dx.doi.org/10.1006/jaar.1998.0335 
Bloszies, C., Forman, S.L. \& Wright, D.K. 2015. Water level history for Lake Turkana, Kenya in the past 15,000 years and a variable transition from the African Humid Period to Holocene aridity. Global and Planetary Change 132, 64-76. http://dx.doi.org/10.1016/j.gloplacha.2015.06.006

Bower, J.R.F. 1991. The Pastoral Neolithic of East Africa. Journal of World Prehistory 5, 49-82. http://dx.doi.org/10.1007/ BF00974732

Bower, J.R.F., Nelson, C.M., Waibel, A.F. \& Wandibba, S. 1977. The University of Massachusetts' Later Stone Age/Pastoral 'Neolithic' comparative study in Central Kenya: An overview. Azania 12, 119-146. http://dx.doi. org/10.1080/00672707709511251

Cavalli-Sforza, L.L. 2000. Genes, Peoples, and Languages. North Point Press, New York.

Collett, D.P. \& Robertshaw, P.T. 1983. Pottery traditions of early pastoral communities in Kenya. Azania 18, 107-125. http:// dx.doi.org/10.1080/00672708309511317

Davies, M.I.J. 2013. Stone cairns across eastern Africa: a critical review. Azania: Archaeological Research in Africa 48 (2), 218-240. http://dx.doi.org/10.1080/0067270X.2013.789207

Dixon, P.M. 2006. Ripley's K Function. Encyclopedia of Environmetrics. John Wiley \& Sons, Ltd.

Ehret, C. 1998. An African Classical Age: Eastern and Southern Africa in World Prehistory History, 1000 BC to AD 400. University Press of Virginia, Charlottesville.

Ehret, C. 2002. The Civilizations of Africa: A History to 1800. University of Virginia Press, Charlottesville.

Ehret, C. 2011. History and the Testimony of Language. University of California Press, Berkeley.

Ehret, C. 2013. Sub-Saharan Africa: linguistics. In: Bellwood, P. (ed.), The Global Prehistory of Human Migration. John Wiley and Sons, Malden, Massachusetts, pp. 96-106. http://dx.doi. org/10.1002/9781444351071.wbeghm812

Forman, S.L., Wright, D.K. \& Bloszies, C. 2014. Variations in water level for Lake Turkana in the past 8500 years near Mt. Porr, Kenya and the transition from the African Humid Period to Holocene aridity. Quaternary Science Reviews 97, 84-101. http://dx.doi.org/10.1016/j.quascirev.2014.05.005

Garcin, Y., Melnick, D., Strecker, M.R., Olago, D. \& Tiercelin, J.-J. 2012. East African mid-Holocene wet-dry transition recorded in palaeo-shorelines of Lake Turkana, northern Kenya Rift. Earth and Planetary Science Letters 331-332, 322-334. http://dx.doi.org/10.1016/j.eps1.2012.03.016

Grillo, K.M. \& Hildebrand, E.A. 2013. The context of early megalithic architecture in eastern Africa: the Turkana Basin c. 5000-4000 BP. Azania: Archaeological Research in Africa 48 (2), 193-217. http://dx.doi.org/10.1080/006727 0X.2013.789188

Hildebrand, E. \& Grillo, K. 2012. Early herders and monumental sites in eastern Africa: dating and interpretation. Antiquity 86 , 338-352. http://dx.doi.org/10.1017/S0003598X00062803
Hildebrand, E., Shea, J. \& Grillo, K. 2011. Four middle Holocene pillar sites in West Turkana, Kenya. Journal of Field Archaeology 36, 181-200. http://dx.doi.org/10.1179/009346 911X12991472411088

Lynch, B.M. \& Robbins, L.H. 1978. Namoratunga: The first archeoastronomical evidence in sub-Saharan Africa. Science 200, 766-768. http://dx.doi.org/10.1126/science. 200.4343 .766

Lynch, B.M. \& Robbins, L.H. 1979. Cushitic and Nilotic prehistory: New archaeological evidence from north-west Kenya. Journal of African History 20 (3), 319-328. http://dx.doi. org/10.1017/S0021853700017333

Morrissey, A. \& Scholz, C.A. 2014. Paleohydrology of Lake Turkana and its influence on the Nile River system. Palaeogeography, Palaeoclimatology, Palaeoecology 403 (1), 88-100. http://dx.doi.org/10.1016/j.palaeo.2014.03.029

Nash, B.P., Merrick, H.V. \& Brown, F.H. 2011. Obsidian types from Holocene sites around Lake Turkana, and other localities in northern Kenya. Journal of Archaeological Science 38 (6), 1371-1376. http://dx.doi.org/10.1016/j.jas.2011.02.001

Ndiema, E. 2011. Mobility and Subsistence Patterns among mid Holocene Pastoralists at Koobi Fora, Northern Kenya. Rutgers University, New Brunswick, New Jersey.

Ndiema, E.K., Dillian, C.D. \& Braun, D.R. 2010. Interaction and exchange across the transition to pastoralism, Lake Turkana, Kenya. In: Dillian, C.D. \& White, C.L. (eds.), Trade and Exchange: Archaeological Studies from History and Prehistory. Springer, New York, pp. 95-110. http://dx.doi. org/10.1007/978-1-4419-1072-1_6

Ndiema, E.K., Dillian, C.D., Braun, D.R., Harris, J.W.K. \& Kiura, P.W. 2011. Transport and subsistence patterns at the transition to pastoralism, Koobi Fora, Kenya. Archaeometry 53 (6), 1085-1098. http://dx.doi.org/10.1111/j.14754754.2011.00595.x

Nelson, C.M. 1993. Evidence for early trade between the coast and interior of East Africa. In: WAC Mombassa Intercongress Conference Volume. Mombasa.

Preacher, K.J. 2001. Calculation for the chi-square test: An interactive calculation tool for chi-square tests of goodness of fit and independence [Computer software]. Available from http://quantpsy.org.

Reimer, P.J., Bard, E., Bayliss, A., Beck, J.W., Blackwell, P.G., Bronk Ramsey, C., Buck, C.E., Cheng, H., Edwards, R.L., Friedrich, M., Grootes, P.M., Guilderson, T.P., Haflidason, H., Hajdas, I., Hatté, C., Heaton, T.J., Hoffmann, D.L., Hogg, A.G., Hughen, K.A., Kaiser, K.F., Kromer, B., Manning, S. W., Niu, M., Reimer, R.W., Richards, D.A., Scott, E.M., Southon, J.R., Staff, R.A., Turney, C.S.M. \& van der Plicht, J. 2013. IntCal13 and Marine13 radiocarbon age calibration curves $0-50,000$ years cal BP. Radiocarbon 55 (4), 1869-1887.http://dx.doi.org/10.2458/azu_js_rc.55.16947

Robbins, L.H. 1980. Lopoy: A Late Stone Age Fishing and Pastoralist Settlement in the Lake Turkana Basin, Kenya. Anthropological Series 3 (1). Michigan State University Museum, East Lansing. 
Robbins, L.H. 1984. Late prehistoric and aquatic adaptations west of Lake Turkana, Kenya. In: Clark, J.D. \& Brandt, S.A. (eds.), Hunters to Farmers: Causes and Consequences of Food Production in Africa. University of California Press, Berkeley, pp. 206-211.

Robbins, L.H. \& Lynch, M. 1978. New evidence on the use of microliths from the Lake Turkana Basin, East Africa. Current Anthropology 19 (3), 619-620. http://dx.doi. org/10.1086/202155

Robertshaw, P. 1984. Archaeology in eastern Africa: Recent developments and more dates. Journal of African History 25 (4), 369-393. http://dx.doi.org/10.1017/S0021853700028449

Robertshaw, P. 2013. Sub-Saharan Africa: Archaeology. In: Bellwood, P. (ed), The Global Prehistory of Human Migration. John Wiley and Sons, Malden, Massachusetts, pp. 107-114. http://dx.doi.org/10.1002/9781444351071.wbeghm813

Schlee, G. 1989. Identities on the Move. Manchester University Press, Manchester, United Kingdom.

Soper, R. \& Lynch, M. 1977. The Stone-Circle Graves at Ng'amoritung'a, Southern Turkana District, Kenya. Azania: Archaeological Research in Africa 12, 193-208. http://dx.doi. org/10.1080/00672707709511255
Soper, R.C. 1989. History of pottery in Kenya. In: Barbour, J. \& Wandibba, S. (eds.), Kenyan Pots and Potters. Oxford University Press, Nairobi, pp. 6-26.

Stewart, K.M. 1989. Fishing Sites of North and East African in the Late Pleistocene and Holocene: Environmental Change and Adaptation. BAR International Series 521, Oxford.

Wandibba, S. 1980. The application of attribute analysis to the study of Later Stone Age/Neolithic pottery ceramics in Kenya. In: Leakey, R.E. \& Ogot, B.A. (eds.), Proceedings of the 8th Panafrican Congress of Prehistory and Quaternary Studies Nairobi September 1977. The International Louis Leakey Memorial Institute for African Prehistory, Nairobi, pp. 283-285.

Wright, D., Forman, S., Kiura, P., Bloszies, C. \& Beyin, A. 2015 Lakeside view: Sociocultural responses to changing water levels of Lake Turkana, Kenya. African Archaeological Review 32 (2), 335-367. http://dx.doi.org/10.1007/s10437015-9185-8

Wright, D.K. \& Forman, S.L. 2011. Holocene occupation of the Mount Porr strand plain in southern Lake Turkana, Kenya. Nyame Akuma 76, 47-62. 